To appear in: Proceedings of the 1st International Conference on Linguistic and Intercultural Education. Alba Iulia: Aeternitas, 2008. 636-682.

\title{
“KIEZDEUTSCH GOES SCHOOL" - A MULTI-ETHNIC VARIETY OF GERMAN FROM AN EDUCATIONAL PERSPECTIVE
}

\author{
Kerstin Paul, Ulrike Freywald, Eva Wittenberg \\ University of Potsdam, Germany
}

\begin{abstract}
This article presents linguistic features of and educational approaches to a new variety of German that has emerged in multi-ethnic urban areas in Germany: Kiezdeutsch ('Hood German'). From a linguistic point of view, Kiezdeutsch is very interesting, as it is a multi-ethnolect that combines features of a youth language with those of a contact language. We will present examples that illustrate the grammatical productivity and innovative potential of this variety. From an educational perspective, Kiezdeutsch has also a high potential in many respects: school projects can help enrich intercultural communication and weaken derogatory attitudes. In grammar lessons, Kiezdeutsch can be a means to enhance linguistic competence by having the adolescents analyse their own language. ${ }^{1}$
\end{abstract}

Keywords: German, Kiezdeutsch, multi-ethnolect, migrants' language, language change, educational proposals

\section{$1 \quad$ Introduction}

In urban areas all over Europe, there has emerged a new type of linguistic varieties in multi-ethnic quarters in recent decades. The speakers of these varieties are adolescents, mainly with a migration background. The development of such urban dialects has been observed and (socio-)linguistically described in a number of European countries, e.g. Rinkebysvenska in Sweden ('Rinkeby Swedish', Rinkeby being a part of Stockholm) (Kotsinas 1992, Fraurud 2003, Bijvoet 2003), københavnsk multietnolekt ('Copenhagen multi-ethnolect') in Denmark (Quist 2005), or straattaal ('street language') in the Netherlands (Nortier 2001, Appel 1999).

All of those varieties display certain common characteristics. Being developed and used mainly by young people with different linguistic backgrounds, they carry properties of youth languages as well as of contact languages. Typical features in this respect are on the one hand influences from the languages of origin, such as lexical borrowing, and on the other hand the loosening of grammatical restrictions, such as morphological and syntactic reduction.

\footnotetext{
${ }^{1}$ Our research was partly supported by funding from the German Research Foundation (DFG) awarded to the Collaborative Research Center "Information Structure" of Potsdam University and Humboldt-University Berlin, project B6 "Kiezdeutsch" (PI: Heike Wiese). We would like to thank Heike Wiese and Horst Simon for help and useful comments - as well as the students and teachers with whom we worked.
} 
Apart from the linguistic analysis one has to take into account that using a multiethnolect constitutes an important factor in the construction of young people's identities. It serves as a means to express their hybrid self-perception between the culture they live in and the culture of their ethnic background.

In this article, we will concentrate on the German variety which can be found in multiethnic areas of the larger cities of Germany, such as Berlin, Hamburg, and Frankfurt/ Main among others. - There is a strong correlation between ethnic and social factors: Kiezdeutsch is mainly spoken in areas with a low average household income, a high unemployment rate and low educational achievement.

In Germany, there exist several denominations to refer to this variety: "Gemischtsprechen" ('mixed talking') (Hinnenkamp 2005), "Türkendeutsch" ('Turks' German') (Androutsopoulos 2001a, Kern \& Selting 2006), "Ghettodeutsch" ('Ghetto-German') (Keim 2004), "Kanak Sprak" ('wog language') (Zaimoğlu 1995, more and more restricted to the stylised variants), and "Kiezdeutsch"" ('Hood German') (Wiese 2006).

In the following section we will sketch properties of Kiezdeutsch that justify the analysis as a variety that merges features of contact languages, multi-ethnolects and youth languages. In section 3, a brief overview over constitutive grammatical features of Kiezdeutsch is given. This outline is followed by a discussion of beliefs maintained by the general public with regard to Kiezdeutsch and its stylised variants, in particular as they are transported by mass media (section 4). Then we will present three exemplary projects dealing with Kiezdeutsch that were realised in different schools in Berlin (section 5). Subsequently, results from the projects are discussed and first conclusions for education are drawn.

\section{Kiezdeutsch - a contact-induced, multi-ethnic youth language}

As mentioned above, Kiezdeutsch - like its European equivalents - bears typical signs of a contact language, such as greater flexibility in the organisation of linguistic expressions (compared to the majority language), morphosyntactic reduction, and integration of lexical items from the different ancestral languages of its speakers. With Wiese (2006) we therefore consider Kiezdeutsch a variety that combines characteristics of a contact and a youth language, for apart from influences from Arabic, Turkish, Kurdish, and Persian, Kiezdeutsch is strongly influenced by current youth culture. In the future, when the group of speakers might possibly not be restricted to adolescents any more, Kiezdeutsch could develop into an "urban dialect" (Wiese 2006: 250), just as it happened in cities like Buffalo or Detroit, where phonological and morphosyntactic features with their origins in immigrants' ethnolects formed a "mainstream urban variety" (Wölck 2002: 161).

\footnotetext{
${ }^{2}$ Kiez is a denomination for 'neighbourhood in Berlin'. It is used in particular by locals to refer to the quarter they live in (cf. mein Kiez 'my neighbourhood').
} 


\subsection{What makes Kiezdeutsch a contact language and a multi-ethnolect}

Speakers of Kiezdeutsch typically live - as already mentioned - in multi-ethnic areas of large German cities. Most of them belong to the second or third generation of migrants in Germany. With their parents, they speak their ancestral language (e.g. Turkish, Arabic, Kurdish, Persian, Polish, etc.). In more formal situations, they usually use more or less colloquial Standard German. Thus, it is only in certain situations that Kiezdeutsch is used.

Kiezdeutsch differs considerably from the fossilised German spoken by the first generation of immigrants who came to Germany in the 1960s (so-called "Gastarbeiterdeutsch", lit.: 'guest-worker German'). Although Kiezdeutsch is often considered to be a case of incomplete language acquisition (e.g. in Loentz 2006: 37), it is more than a learner language, so that 'Gastarbeiterdeutsch' can at best be regarded as one of the sources of influence for Kiezdeutsch. The two main reasons for this are: Firstly, speakers also use Standard German variants - they are usually able to switch between Kiezdeutsch and Standard German (Wiese 2006: 251). Secondly, not only adolescents with migration background use this variety, but native speakers of German employ it as well (cf. Wiese 2006: 253f). This is a constellation comparable to the phenomenon of Crossing, which can be described as "switching into languages that are not generally thought to belong to you" (Rampton 1995: 280). It differs, however, from prototypical forms of code-switching in that "there is a distinct sense of movement across social or ethnic boundaries" (ibid.).

Hence, the term 'multi-ethnolect' reflects rather accurately the linguistic characteristic of Kiezdeutsch. Clyne (2000: 87) uses this term and distinguishes between "multiethnolect" and "lingua franca". While a lingua franca serves pragmatically as an "intermediary code" (Clyne 2000: 83) between speakers of different native languages, multi-ethnolects have a supplementary expressive content as being used by different ethnic minority groups together to embody their group identity and their position to the majority society (ibid.). Another important point is that Kiezdeutsch is more or less restricted to a special age group, namely adolescents, so that it can also be considered a youth language.

\subsection{What makes Kiezdeutsch a youth language}

The use of Kiezdeutsch marks a particular situation of communication. Adolescents make use of Kiezdeutsch in order to draw a line between other groups, such as siblings, parents, teachers, and adults in general, and themselves. Kiezdeutsch represents a distinctive mark, it functions as a special peer group code.

This is not surprising, as language use in adolescence can be seen as a symbolic assertion of autonomy and as an index of affiliation to (or distancing from) relevant peer groups and youth-cultural scenes and as a demarcation to the world of the adults. In Pujolar's words, "the use of particular speech varieties in the context of youth culture is an important part of the processes whereby young people construct their views about the world and their relationships amongst themselves and with other social groups" (Pujolar 2001: 7). Kiezdeutsch thus also serves to construct a peer-group identity. 
The grammatical system of Kiezdeutsch is not as all as arbitrary or even chaotic as it might seem at first glance. It exhibits stable morphological and syntactic patterns of its own. One remarkable innovation is, for instance, the development of new information structural strategies.

Grammatical features of Kiezdeutsch include not only phenomena of grammatical reduction, but Kiezdeutsch also expands given structural options in terms of overgeneralisation of patterns that already exist in Standard German. This is a strategy quite common in contact languages (Kotsinas 2001: 130, Silva-Corvalán 1990: 163) and in foreign language acquisition (Herron 1991: 967ff).

In what follows, we will briefly present some morphosyntactic and lexical characteristics to illustrate the linguistic system of Kiezdeutsch.

\subsection{Morphosyntactic reduction: bare nominals as local adverbials}

A conspicuous instance of morphosyntactic reduction is the use of bare noun phrases (NP) instead of prepositional phrases (PP) as local adverbials. In Standard German, this type of construction is strictly restricted to names of stops of public transport (cf. Wiese 2008), as illustrated in (1) (Alexanderplatz refers to a square and a tube station in Berlin): ${ }^{3}$

$$
\begin{aligned}
& \text { Ich steige Alexanderplatz um. } \\
& \text { I get } \quad \text { Alexanderplatz over } \\
& \text { 'I change trains at Alexanderplatz.' }
\end{aligned}
$$

[Standard German]

In Kiezdeutsch, however, bare NPs are employed regularly for local and directional adverbials. In example (2), the bare NP Arbeitsamt expresses the goal of the movement, whereas in Standard German, the PP zum Arbeitsamt ('to the job centre') would have been to be used: ${ }^{4}$

$$
\begin{aligned}
& \text { Morgen ich geh Arbeitsamt. } \\
& \text { tomorrow I go job.centre } \\
& \text { 'Tomorrow I'll go to the job centre.' }
\end{aligned}
$$

[Kiezdeutsch]

What can be seen here is another case of expansion of structural possibilities by overgeneralising majority language structures.

\footnotetext{
${ }^{3}$ The following examples of Kiezdeutsch are utterances by speakers from Berlin-Kreuzberg and Berlin-Neukölln. They were collected in 2007 by a research group under the guidance of Heike Wiese at the University of Potsdam.

${ }^{4}$ The sentence in (2) exemplifies another syntactic pattern typical for Kiezdeutsch as well: It shows 'adverbial - subject - finite verb' order instead of the obligatory verb second structure one would have to expect in Standard German (compare: Morgen gehe ich zum Arbeitsamt.) (for a broader discussion of this construction in Kiezdeutsch see Wiese 2008; Freywald, in prep.).
} 


\subsection{Light verb constructions}

Another occurence of generalising Standard German patterns is the productive use of light verb constructions (in German: Funktionsverbgefüge). In Standard German, light verb constructions consist of a semantically bleached light verb combined with a morphosyntactically reduced $\mathrm{NP}$, as in $(3):^{5}$

$$
\begin{aligned}
& \text { Der Vorschlag steht } \text { zur } \\
& \text { The proposal stands to.the } \\
& \text { 'The proposal is up for discussion. } \\
& \text { discussion. }
\end{aligned}
$$

While in Standard German, light verb constructions are barely productive, they are highly productive in Kiezdeutsch (Wiese 2006: 258-268):

$$
\begin{aligned}
& \text { Machst du rote Ampel. } \\
& \text { do you red traffic.lights } \\
& \text { 'You cross the street on a red light.' }
\end{aligned}
$$

[Kiezdeutsch]

This way of forming periphrastic constructions (instead of using synthetic expressions) provides more flexible information structural means. By employing light verb constructions, speakers of Kiezdeutsch shift the relevant information (rote Ampel 'red lights' in (4)) into a strong focus position, namely the last position in the sentence. Furthermore, as the verbs used in those new light verb constructions stem from a very salient and productive class, they open up a broad pattern: Fewer verbs are needed in order to construct a variety of meanings (see Wiese 2006, 2008 for a detailed discussion of light verb constructions in Kiezdeutsch).

\subsection{New focus marking particles}

The wide-spread use of particles (partly already existent in Standard German, partly newly developed or borrowed) is typical for Kiezdeutsch, both as a contact language and as a youth language (cf. also the next paragraph). The usage of the particle so, for instance, differs from the corresponding lexeme in Standard German. ${ }^{6}$ In Kiezdeutsch, so can be followed by a noun without determiner, which is not - or at least not to that extent - possible in Standard German. In Kiezdeutsch, so is used as a focus particle indicating the following constituent as focussed (Paul 2008; Wiese 2007; Paul, Wittenberg \& Wiese, subm.). It does not add any lexical meaning, cf. (5): ${ }^{7}$

\footnotetext{
5 'Morphosyntactically reduced' means here that the noun involved is restricted with regard to marking of number and definiteness and to attributive modifying. Furthermore, it is not referable to by anaphoric pronouns. For light verb constructions in Standard German, see e.g. Eisenberg (1999: 299-307) and Duden (2005: 424-432).

${ }^{6}$ For a discussion of functions of so in Standard German, see e.g. Hole \& Klumpp (2000), Lenerz \& Lohnstein (2005), and Auer (2007).

${ }^{7}$ This function is comparable to American English colloquial like (Heike Wiese, p.c.); for a discussion of like in English, see, among others, Underhill (1988), Meeham (1991), and Fox Tree (2006).
} 


$$
\begin{aligned}
& \text { Ich mag so } \quad \text { Wasserpfeifeladen. } \\
& \text { I like } \\
& \text { 'I enjoy, like, shisha-shops.' }
\end{aligned}
$$

With this particle, information structural means in Kiezdeutsch (and perhaps as well in spoken colloquial German) are being substantially expanded. ${ }^{8}$

\subsection{Lexical borrowings}

Lexical elements like swearwords, vulgarisms or insults are often borrowed from migrant languages. Such expressions are also typical of youth languages. Foreign words that adults cannot understand properly are a strategy to distance oneself and to build up a peer group identity.

Lexemes such as wallah (an Arabic borrowing, lit.: 'by God') or ischwör (a contraction of former ich schwöre 'I vow') serve as means of strengthening and assertional affirmation. In Kiezdeutsch, they have the status of discourse particles (Wiese 2008).

$$
\begin{aligned}
& \text { Ischwör Alter, war so. } \\
& \text { PTCL old.man was so } \\
& \text { 'Really, dude, it was like that.' }
\end{aligned}
$$

$$
\begin{aligned}
& \text { Und da stand und hat mir seine Hand gegeben. Wallah. } \\
& \text { and there stood and has me his hand, given } \\
& \text { 'And he stood there and shook hands with me. Really.' }
\end{aligned}
$$

Another popular term is Turkish çüş, which can mean 'Go!' or 'Play up!', but also 'You fool!' and 'You ass!' (originally 'Whoa!', said to stop a donkey), as example (8), a song text, illustrates:

$$
\begin{aligned}
& \text { Çüş Junge ich komm gar nicht mehr klar } \\
& \text { PTCL boy I come PTCL no more clear } \\
& \text { sie ist das Beste aus } 2 \text { Welten guck sie sitzt an der Bar } \\
& \text { she is the best of two worlds look she sits at the bar } \\
& \text { Çüş Junge } \\
& \text { PRTC boy } \\
& \text { sie ist heute abend } \\
& \text { she is today evening the star }
\end{aligned}
$$

'Hey guy, I don't get along any more / she is the best one of two worlds, look, she is sitting at the bar / hey, guy / tonight, she is the star' (Fler [2008]. Çüş Junge. Lyrics. Retrieved Aug 8, 2008, from http://www.magistrix.de/lyrics/Fler/Cues-Junge-91418.html)

\footnotetext{
${ }^{8}$ Similar developments can be observed in Swedish where the particle $b a r a / b a{ }^{\prime}$ develops comparable discourse functions, e.g. in the information structural domain, cf. Erman \& Kotsinas (1993).
} 
There are also several denominations for addressing peers, such as lan (Turkish: 'man, guy'), moruk (Turkish: 'old man') or Alder (colloquial German: 'old man'). Alder and moruk both have lost the meaning 'old' and are now neutral forms of address.

The field of introduction and closing remarks is generally open to change in youth languages. Accordingly, one finds ever-changing lexical borrowings from migrant languages, two more examples are shu (an Arabic borrowing for saying Hello! / Hi! and Good-bye!) and hadi (Turkish: 'Come on!') in Kiezdeutsch, cf. (9) from a music weblog:

$\begin{array}{llllllll}\text { shuu mafiosoo } & \text { miezerr } & \text { track } & \text { ja } & \text { sowieos } & \text { wenn } & \\ \text { PTCL mafioso } & \text { lousy } & \text { track } & \text { yes } & \text { anyhow when } & \\ \text { crimetime music } & \text { vor } & \text { kommt } & \text { :P } & \text { nein man hadi digga } \\ \text { C. } & \text { music PTCL comes } & \text { EMOTICON no man } & \text { PTCL fatty } \\ \text { macxh weiter soo wir sehn } & \text { uns schreib zueück } & \\ \text { do further so we see us write back } & \end{array}$

'Hi mafioso, lousy track, yes indeed, it's always like that when music by Crimetime comes into play, no, man, come on, fatty, carry on like that, we see each other, write back.'

(anonymous posting [2008]. Blog of Mafioso NeunUndZwanzig at MySpace.com. Retrieved Aug 8, 2008, from

http://profile.myspace.com/index.cfm?fuseaction=user.viewprofile\&friendid $=227553937$; orthography as in the original; italics are ours, $\mathrm{P} / \mathrm{F} / \mathrm{W}$ )

While the structures in (2), (4) and (5) are ungrammatical and foreign vocabulary as illustrated in (6) - (9) does not exist in Standard German, they are used systematically in Kiezdeutsch. Unsurprisingly, a certain public opinion on this seemingly 'wrong' or 'degenerated' variant of German has evolved. The following section provides - after a brief description of stylised variants of Kiezdeutsch - an analysis of general attitudes towards Kiezdeutsch and its speakers as well as social problems resulting therefrom.

\section{$4 \quad$ Kiezdeutsch in the public opinion}

In Germany, it is quite popular to imitate Kiezdeutsch, often in a very derogative way. This stylised variant is usually called Kanak Sprak ('wog language'). It has been disseminated by mass media, particularly in comedy shows (cf. Kotthoff 2004 for examples, Auer 2003 for processes of stylisation). Nowadays, a large number of German speakers are able to reproduce typical expressions or words and the manner of a 'Kanak'.

Stylised expressions of Kiezdeutsch are often used to establish negative social stereotypes. ${ }^{9}$ For instance, comedians often impersonate speakers of Kiezdeutsch. As Androutsopoulos (2001a,b, 2005) has shown, such stylised figures tend to reflect stereotypical images of certain social categories. 'Ethno-comedians' like Erkan \&

\footnotetext{
${ }^{9}$ As Androutsopoulos (2001b) points out, stylised expressions bear not necessarily a discriminating connotation, sometimes they are just used to show one's knowledge of the current media discourse.
} 
Stefan or Kaya Yanar aim to exaggerate linguistic behaviour of minorities. A part of Erkan \& Stefan's song "Ich schwör" reads like that:

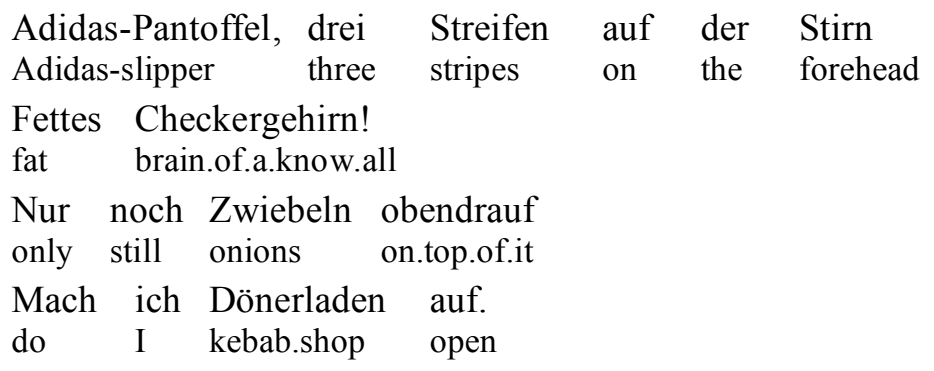

'Adidas-slippers, three stripes on the forehead / fat know-all! / just onions on top of it / I open a kebab shop.'

(Erkan \& Stefan: "Ich schwör", single CD of the same title, published 1999, Label: Lawine (Virgin, EMI))

Here, the transported stereotype is the image of a Turk who is simple-minded, badlydressed and rowdyish. Although comedy intends to evoke such images and, by exaggeration, also criticises these stereotypes and images of the outsiders' view of migrants in Germany (cf. Kotthoff 2004), these stylisations are perhaps one reason for the bad image of Kiezdeutsch. As Milroy (1998: 64f) puts it: "In an age when open discrimination in terms of race, colour, religion or gender is not publicly acceptable, the last bastion of overt social discrimination will continue to be a person's use of language."

Thus, the public opinion about Kiezdeutsch is predominantly negative and depreciative. A teacher from Berlin, for example, presumes a degeneration of language: ${ }^{10}$

Sie sprechen in Fetzen, die Syntax ist vereinfacht. Das trägt zum Verfall der deutschen Sprache bei.

'They speak in shreds, the syntax is simplified. That contributes to the deterioration of the German language.'

(Primary school teacher, informal interview, Berlin 2004, cited in Wiese 2008)

Even a high-profile politician found harsh words to express her attitude towards this kind of speaking:

Ich sage Ihnen, ich würde immer dazwischen gehen, wenn zwei sich auf der Straße so unterhalten, ich sage, ihr Arschlöcher, das ist der Anfang vom Ende! So fangen sie an miteinander zu reden!

'I tell you, I'd always interrupt when two are talking like that on the street. I'd say, you assholes, that's the beginning of the end! This way they start talking!'

(Heide Simonis, a former German regional prime minister, in the talkshow "III nach neun", Norddeutscher Rundfunk, May 8, 1998)

\footnotetext{
${ }^{10}$ This attitude is not restricted to German speaking countries. Harris (2003), for example, notes that those particular processes of language change are generally seen as a loss - in a mood Harris calls "melancholia of language shift".
} 
Successful students with a migration background, such as Turkish or Arabic, seem to be great exceptions. This fact is mirrored and reflected ironically by the following statement of a young woman with Turkish background:

Meine Muttersprache ist Türkisch, dennoch spreche ich Deutsch und das auch noch fließend - sogar akzentfrei. [...] Doch es kommt noch härter, die DeutschTürkin hat ihr Studium erfolgreich absolviert. [...] Demnächst werde ich in den deutschen Staatsdienst eintreten und euren Kindern demokratische Werte und Normen vermitteln.

'My native language is Turkish. Nevertheless, I speak German, even fluently and, moreover, without accent. [...] But it's even worse: The German-Turk has finished her studies successfully. [...] Soon, I'll be a civil servant and teach your children democratic values and norms.'

(Funda Gümüşdağ, *1982 in Berlin, Greve \& Nur Orhan 2008: 46)

This scenario leads to social problems. Adolescents with a migration background fail much more often at school than German pupils. They reach significant lower results in achievement tests like PISA compared to children without a migration background, especially concerning reading literacy, although most of them are born in Germany and run through the same school system. Many of them leave school without or with the lowest graduation. The percentage of migrant students at Hauptschule (school leading to a basic exam after nine or ten years) is twice as large as the percentage of German students - migrants also make the biggest part of drop-outs $(15.1 \%$ of migrants leave school without graduation) (Gogolin et al. 2003: 54ff). On the other hand, relatively few pupils continue through to A-levels; moreover, youths with migration background have a high unemployment rate (cf. Greve \& Nur Orhan 2008: 43 for data from Berlin).

Reasons for the difficulties of migrant youths on the labour market are surely multidimensional. But there are often ethnic attributions, prejudices and other implicit mechanisms behind the fact that migrants have disadvantages on the labour market, be it that a migrant is not trusted to pass exams because of a reputed foreign accent or that girls with a migration background are advised against an apprenticeship in nursery school because of their religion (see Boos-Nünning 1999). Thus, it is important to initiate further research on means to develop new ways for migrants out of social stigmatisation and isolation.

Similar to the case of "Ebonics" in the U.S. - here understood as a synonym for African-American Vernacular English or Black English,$-{ }^{11}$ there are two ways to tackle these problems:

1. Train Kiezdeutsch speakers to use different varieties appropriate to the respective situation;

2. Train the public to be aware of social discrimination based on an individual's use of language.

In what follows, we will present three projects dealing with Kiezdeutsch as an educational matter that were realised in two German state schools and during an American Summer College class in Berlin, respectively. We will show that working on subjects

\footnotetext{
${ }^{11}$ See for details of the Ebonics debate, e.g., Baugh (2000) and Green (2002).
} 
related to language and grammar can sensitize young students - both with and without migration background - to stereotypes and language attitudes of their own and others.

\section{$5 \quad$ School projects \\ 5.1 Essence and purpose of Kiezdeutsch at school}

In this section, we will outline the possibilities Kiezdeutsch gives teachers and researchers in order to not only raise interest in grammar lessons, but also in order to reach aims which consist in the development of tolerance and multicultural understanding. On the one hand, adolescents get the opportunity to reflect upon their own language and the speech styles of their own generation. On the other hand, they are sensitized to language use and the suitability of registers and varieties in different situations. Furthermore, by being concerned with different varieties, their skills in formulating effectively are enriched.

At first glance, it seems counter-productive to deal with Kiezdeutsch at school because the aim there is to learn 'proper' German. But a closer look reveals that many advantages can be gained by discussing a multi-ethnic youth language with pupils and young students:

Regarding students with migration background. Studies have shown that the pedagogical coordination of the first and second language of bilingual children is important for a productive language promotion (see, for example, the language promotion program "FörMig"12). Thus, apart from teaching students their respective native languages, integrating Kiezdeutsch in German classes can serve as an important link between the languages.

Regarding students without migration background. Students without migration background can profit from the discussion about linguistic variation, too. Regarding youth language in general, Neuland (2006) highlights the importance of such a topic e.g. in grammar lessons or with respect to the subjects "reflection about language" or "oral and written language use". She mentions several domains in which youth language as a subject can enhance linguistic competences (p. 233):

- analytical competences and knowledge of the German language;

- productive competences and knowledge of effects of speech styles;

- reflective competences and the ability to assess language use in an informed way.

What Neuland formulates for youth language can, from our point of view, be even better reached by discussing Kiezdeutsch because the public discussion is even more stimulating. As we have seen in section 4, there are lively debates going on about Kiezdeutsch. Students in particular show to be very opinionated regarding language and youth language.

Kiezdeutsch in the curricula of Germany. Looking at Standard German course materials, the topic "language criticism" is scheduled for the two final years before Alevel exams (Abitur) in Germany. Matters in this context cover, among others, trends

\footnotetext{
12 "FörMig" stands for "Förderung von Kindern und Jugendlichen mit Migrationshintergrund" ('Promotion of children and adolescents with migration background'), for further details see the ressources on the internet: http://www.blk-foermig.uni-hamburg.de.
} 
in the development of contemporary German, language as an instrument for social and political interests, and relations between language and mind. ${ }^{13}$

It would be advisable to choose Kiezdeutsch as one topic in this context and to analyse this variety from different perspectives, such as:

- public opinion / prejudices against Kiezdeutsch;

- Kiezdeutsch as a youth style;

- "Kanak Sprak" as stylisation of Kiezdeutsch;

- Kiezdeutsch and language change (grammatical features of Kiezdeutsch).

With younger pupils, also regional and social varieties of German in general should be discussed, among them youth language. ${ }^{14}$ The kind of discussion will be slightly different in that case, but the aims are equivalent.

As we have seen, youth language does occur as a topic in school books - but it is often represented by examples that have undergone an educational stylisation process. The effect is that texts in youth language tend to be artificial or even antiquated and do not mirror the current situation. Another aspect to criticize is the type of tasks and aims that are connected with such texts: Translation tasks, for instance, are an inadequate means to make variation evident as they have a tendency to overemphasise the differences between the two linguistic codes; they insinuate the incomprehensibility of youth language for the older generation. Unfortunately, doing grammar with youth language is never a topic and the students are rarely encouraged to experiment with youth language (see also Neuland 2006: $231 \mathrm{ff}$ ).

To learners of German as a foreign language, also the discussion of varieties besides Standard German is profitable, for the following reasons:

- Learners get to know an actually spoken form of the language they are learning. They also get acquainted with colloquial and sub-standard registers.

- In order to demonstrate linguistic variation, Kiezdeutsch is more appropriate than German dialects would be. As Kiezdeutsch is a youth language, it can be compared with adolescents' talk in the learners' native language(s).

- Kiezdeutsch includes words and expressions from a wide range of languages - it can be inspiring and encouraging for language learners to identify words from their own language(s) or third languages.

We conducted several school projects that dealt with Kiezdeutsch during the last few months. The goal of these projects was to enrich intercultural communication and to weaken derogatory attitudes preformed by language ideology. Besides, we intended to make grammar lessons more interesting, e.g. by comparing grammatical patterns of Kiezdeutsch with those of Standard German.

Educational methods. We used projects and open learning concepts (Frey 1990, Gudjons 1994) in order to reach these aims. As these educational concepts are student-

${ }^{13}$ Cf., e.g., the A-levels curriculum provided by the Federal state of Brandenburg, Germany (Pädagogisches Landesinstitut Brandenburg 2003), cf. http://www.bildung-brandenburg.de/.

${ }^{14}$ This being a suggestion within the primary school curriculum provided by the Federal state of Brandenburg, Germany (Ministerium für Bildung, Jugend und Sport des Landes Brandenburg 2008), cf. http://www.bildung-brandenburg.de/. 
centered, the students can learn actively, guided by their own interest in the topic. It is constitutive for such an approach to make the individual interests of the students the starting point of integral teaching. Those interests can also include personal and social aspects. One decisive advantage of using these methods is the positive effect they have on students' cooperative and social learning as well as on reducing prejudices, as numerous studies have shown (e.g. Slavin 1979, Abrami et al. 1995).

In the following sections we will give a short outline of our project design and methods and we will discuss the outcome as well as first didactic conclusions.

\subsection{Kiezdeutsch in the Kiez - a project in multicultural Berlin-Kreuzberg}

This project was realised in a comprehensive school located in Berlin-Kreuzberg, a multicultural and multi-ethnic part of Berlin. The school is currently frequented by about 500 pupils, $85 \%$ of whom have a migration background. This is the prototypical environment for Kiezdeutsch. 12 students aged 15-18 participated in the project.

The purpose of the project was to increase linguistic awareness, to inspire interest in linguistic questions and to awaken the ability to collect, analyse and present data about public opinion on Kiezdeutsch.

From the very beginning, the students developed a strong linguistic awareness. They were able to reflect upon their own way of speaking and upon differences between boys' and girls' speech styles, even though they often lacked appropriate terminology to describe their impressions and experiences.

After a general introduction and a discussion about youth language and Kiezdeutsch and the public opinion about them, the students decided to conduct a survey with people on the street. They developed a questionnaire, and for two days interviewed citizens of different ages and backgrounds in various areas of Berlin about their opinion on Kiezdeutsch, how they had talked themselves when they were younger, and whether they were able to understand today's youth language. The results were rather diverse; generally, people admitted to dislike Kiezdeutsch when it is used "extensively"; they considered the ability to switch between Standard German and Kiezdeutsch very important.

Finally, the participants of the Kiezdeutsch project compiled a presentation for their age group at school. They evaluated the interviews they had made the days before, added their favorite music (rap and hip-hop from Kreuzberg), gave examples of Kiezdeutsch expressions, etc. All in all, the students not only learned basic research methods, but also presentation techniques and, crucially, enhanced their knowledge about linguistic problems.

The schoolmates gave their approval to the presentation of Kiezdeutsch with applause. According to the pupils' schoolmates, the presentation mirrored the life style of the adolescents quite appropriately. These results have shown that the approach of selfidentification and individual experience relation was applied successfully. Students are able to identify with the contents of teaching and learning much better if they get the opportunity to participate in planning and realisation of lessons or learning projects (cf. also Meyer 2005). Concepts of open learning led - as intended - to joint actions and creative approaches to carry out learning tasks. In the end, students were proud of their results and at the same time encouraged in their self-confidence. 


\subsection{Kiezdeutsch far away from the Kiez - a project with speakers of Standard German}

The second project took place at a secondary school that is situated in Braunschweig, a medium-sized city in Northern Germany completely different from the multicultural Kiez in Berlin. The project carried the motto "School with courage, school without racism"; attendants were ca 40 students in their penultimate year of school, aged about 18. The students had exclusively a white middle-class background. Linguistically conservative or even puristic attitudes were very common among them. Multi-ethnic quarters and even the existence of youth language seemed alien for some of them.

Due to restricted time in the classroom, tasks included pre-formulated materials to work on in groups. One task, for instance, aimed at examining Kiezdeutsch from different perspectives and working creatively with the prepared materials.

The four subject areas covered by the project had the following content:

\begin{tabular}{|c|c|c|}
\hline Subject & Aims / Content & Task \\
\hline Grammar & $\begin{array}{l}\text { - Special features of Kiezdeutsch } \\
\text { - Differences between Kiezdeutsch and } \\
\text { Standard German }\end{array}$ & $\begin{array}{l}\text { Creating a phrase-book and } \\
\text { a tourist information } \\
\text { brochure for Berlin- } \\
\text { Kreuzberg }\end{array}$ \\
\hline Stylised variants & $\begin{array}{l}\text { Differences between actually spoken } \\
\text { Kiezdeutsch and stylised variants } \\
\text { - Effects of stylisation }\end{array}$ & Presentation \\
\hline $\begin{array}{l}\text { Language politics } \\
\text { and language } \\
\text { ideology }\end{array}$ & $\begin{array}{l}\text { - Reflection upon the public discussion } \\
\text { - Attitudes and prejudices towards } \\
\text { Kiezdeutsch / youth language } \\
\text { - Formulating an own position }\end{array}$ & $\begin{array}{l}\text { Producing a radio } \\
\text { broadcast, interviews, film }\end{array}$ \\
\hline $\begin{array}{l}\text { Language and } \\
\text { identity }\end{array}$ & $\begin{array}{l}\text { - Cohesion between language and } \\
\text { identity } \\
\text { - Ways to express identity }\end{array}$ & $\begin{array}{l}\text { Presentation, } \\
\text { photo session }\end{array}$ \\
\hline
\end{tabular}

In the upshot of the project, there came out very inventive presentations. The students tried to fulfill our expectations and those of their teachers. It was, however, problematic that they were apparently not used to formulating their own views.

One group of students showed grave puristic attitude. They produced a radio broadcast which presented a conversation between the two protagonists Ali, a speaker of Kiezdeutsch, and the famous German $19^{\text {th }}$ century writer Heinrich von Kleist. They discuss the relation of language and mind. The message transported by this discussion is that a speaker of 'broken' German like Ali is simple-minded and not able to understand complex thoughts. They did not have a sense of how severely they were discriminating against other people and they were obviously not able (or not willing) to empathise with adolescents with multicultural backgrounds. For this group of students, Kiezdeutsch remained a bizarre and weird affair. It would be highly profitable to continue 
this discussion in 'normal' lessons in the future to develop the awareness of ethnic and linguistic variation. ${ }^{15}$

Another group dealt with youth styles and identities. For this group, it became clear that Kiezdeutsch is one possibility to express identity among many other youth styles. Here, the pedagogic goal of deepening the understanding of variation and of the equality of different varieties was achieved. The remaining groups also produced creative and felicitous results, among them a phrase-book, posters, etc.

On the whole, the project can be regarded as successful as the students widened their horizon. The students were confronted with a topic very foreign to them. As they were not used to argue their own positions in a debate, the majority joined the quite conservative opinion of their teachers. It would certainly be useful for them to continue with this topic in regular classes.

\subsection{Kiezdeutsch for learners of German as a foreign language}

Another target group for Kiezdeutsch as an educational matter are learners of German. This perspective was explored with a group of 15 students from a North American University, aged 19 to 22, as part of a Summer College class in Berlin. For those students, who have been learning German for three semesters, it was interesting to discover youth culture and youth language in Germany.

After a short presentation of the phenomenon 'Kiezdeutsch' and the public discussion about it, the students were presented with Kiezdeutsch original citations from our corpora, showing typical phenomena (see section 3), for example sentences like

$$
\begin{array}{lll}
\text { Machst du } & \text { rote Ampel. } & \text { [Kiezdeutsch] } \\
\text { do you red traffic.lights } & \\
\text { 'You cross the street on a red light.' } &
\end{array}
$$

The students' tasks were:

- to describe the phenomenon (i.e., verb first word order in a declarative clause, different from Standard German; deviant meaning of verb);

- to find examples in Standard German where one can find this pattern (i.e. conditionals or yes-no-questions; light verbs);

- to find examples in other languages where one can find this pattern (i.e. Romance languages, for instance).

Especially the last task had important effects on the students: They were able to compare their own - still limited - knowledge of grammar to linguistic patterns in Kiezdeutsch and to patterns in other languages, formulating hypotheses as to why these patterns might be used in a contact variety. For many of those students, these exercises

\footnotetext{
${ }^{15}$ In environments where ethnic diversity is a common situation, prejudices and negative attitudes decrease apparently, as the research project "Urban Classroom Culture and Interaction" has revealed recently. The project was carried out at a multi-ethnic comprehensive school in London. One of its findings was that "[a]dolescents recognised ethnic differences but treated them as secondary in conversations about far more insistent matters (friendship responsibilities, male-female relations, popular media culture etc)“(Rampton et al. 2008: 4-5).
} 
were not only useful but also inspiring, because they helped to shed light on some triggers of their own errors in Standard German.

\section{Conclusion and outlook}

In the present paper we have shown that Kiezdeutsch is to be considered a variety of German in its own right. Its grammatical structures differ systematically from Standard German. It bears features (a) of a contact language, such as morphosyntactic reduction, weakening of grammatical restrictions, and development of periphrastic constructions; (b) of a multi-ethnolect, because it is used by minority groups with different migration backgrounds as well as by native speakers of German to build up a group identity against the majority group; and (c) of a youth language with respect to the restriction to a well-defined age group (adolescents).

The image of Kiezdeutsch and its speakers in the general public is at present firmly linked to depreciation and negative social stereotypes. The resulting discriminating situation gave the impulse to initiate projects at schools where adolescents with migration background can be reached. The intention has been to make non-standard language and grammatical issues part of the lessons. This should provide students with strengthened self-confidence and encourage them to express their identities by means of language use.

The educational projects revealed that for different target groups it can be highly profitable to deal with Kiezdeutsch. To bring Kiezdeutsch into school can generate:

(i) increased linguistic awareness; expanded knowledge of German grammar; reduction of dislike for grammatical issues;

(ii) encouraged self-assurance; ability to face prejudices confidently (particularly in case of speakers of Kiezdeutsch);

(iii) weakening of prejudices and stereotypes (particularly in case of speakers not familiar with Kiezdeutsch);

(iv) increased awareness of variational phenomena; ability to distinguish varieties and speech styles and to use them appropriately;

(v) enrichment of teaching German as a foreign language in terms of considering spoken colloquial and sub-standard varieties instead of Standard German only as well as possible relations to the native language(s) of the learners.

To gain these aims, it is vital that teachers' attitudes to Kiezdeutsch and linguistic variation in general will change. ${ }^{16}$ Therefore, our approach is a possibility to realise the concept of intercultural education (Gogolin \& Krüger-Potratz 2006, Hartung 2004) in German classes by student-centered methods in projects and open-learning situations. We hope to have shown some ways to integrate youth language, and Kiezdeutsch in particular, into regular classes at school so that they can become part of modern German lessons.

\footnotetext{
${ }^{16}$ Similar claims have been made in the UK; cf. Williams (2007) for an overview over the discussion about non-standard varieties of English and their treatment in national curricula.
} 


\section{References}

Abrami, P. C., Chambers, B., Poulsen, C., De Simone, C., d'Apollonia, S., Howden, J. (1995). Classroom Connections: Understanding and Using Cooperative Learning. Toronto: Harcourt Brace.

Androutsopoulos, J. (2001a). Ultra korregd Alder! Zur medialen Stilisierung und Aneignung von “Türkendeutsch", Deutsche Sprache, 29, 321-339.

Androutsopoulos, J. (2001b). From the streets to the screens and back agian: On the mediated diffusion of ethnolectal patterns in contemporary German, Essen: LAUD, Series A, No. 522.

Androutsopoulos, J. (2005). “... und jetzt gehe ich chillen": Jugend- und Szenesprachen als lexikalische Erneuerungsquellen des Standards, in L. M. Eichinger \& W. Kallmeyer (eds.), Standardvariation. Wie viel Variation verträgt die deutsche Sprache? Berlin, New York: de Gruyter, 171-206.

Appel, R. (1999). Straattaal. De mengtaal van jongeren in Amsterdam, Toegepaste Taalwetenschap in Artikelen, 62(2), 39-55.

Auer, P. (2003). 'Türkenslang': Ein jugendsprachlicher Ethnolekt des Deutschen und seine Transformationen, in A. Häcki-Buhofer (ed.), Spracherwerb und Lebensalter. Tübingen: Francke, 255-264.

Auer, P. (2007). Syntax als Prozess, in H. Hausendorf (ed.), Gespräch als Prozess. Linguistische Aspekte der Zeitlichkeit verbaler Interaktion. Tübingen: Narr, 95124.

Baugh, J. (2000). Beyond Ebonics: Linguistic Pride and Racial Prejudice. New York: Oxford University Press.

Bijvoet, E. (2003). Attitudes towards "Rinkeby Swedish", a group variety among adolescents in multilingual suburbs, in K. Fraurud \& K. Hyltenstam (eds.), Multilingualism in Global and Local Perspectives. Papers from the $8^{\text {th }}$ Nordic Conference on Bilingualism, November 1-3, 2001, Stockholm-Rinkeby. Stockholm: Centre for Research on Bilingualism, 307-316.

Boos-Nünning, U. (1999). Gleichbehandlung durch Quotierung? Strategien zur beruflichen Eingliederung junger Zuwanderer, in Forschungsinstitut der FriedrichEbert-Stiftung, Abt. Arbeit und Sozialpolitik (ed.), Integration und Integrationsförderung in der Einwanderungsgesellschaft. Bonn: Friedrich-Ebert-Stiftung, 73-89. Retrieved Aug 8, 2008, from http://www.fes.de/fulltext/asfo/00713b.htm\#LOCE9E7.

Clyne, M. (2000). Lingua franca and ethnolects in Europe and beyond, Sociolinguistica, 14, 83-89.

Duden (2005). Duden. Die Grammatik. Ed. by Dudenredaktion. Mannheim: Dudenverlag.

Eisenberg, P. (1999). Grundriß der deutschen Grammatik. Vol. 2. Der Satz. Stuttgart, Weimar: Metzler.

Erman, B. \& Kotsinas, U.-B. (1993). Pragmaticalization: the case of $b a^{\prime}$ and you know, Studier i modern språkvetenskap, 10, 76-92.

Fraurud, K. (2003). Svenskan i Rinkeby och andra flerspråkiga bostadsområden, in T. Breivik (ed.), Språk i Norden 2003. Oslo: Novus, 62-89.

Fox Tree, J. E. (2006). Placing like in telling stories, Discourse Studies 8. 723-743.

Frey, K. ( $\left.{ }^{3} 1990\right)$. Die Projektmethode. Weinheim, Basel: Beltz. 
Freywald, U. (in prep.). Lo(o)s(en)ing the verb second constraint. Cases of V3 in a multi-ethnic variety of German (Kiezdeutsch).

Gogolin, I., Neumann, U. \& Roth, H.-J. (2003). Förderung von Kindern und Jugendlichen mit Migrationshintergrund. Gutachten. BLK-Materialien zur Bildungsplanung und Forschungsförderung, 107.

Gogolin, I. \& Krüger-Potratz, M. (2006). Einführung in die Interkulturelle Pädagogik. Opladen: Budrich.

Green, L. J. (2002). African American English: A Linguistic Introduction. Cambridge: Cambridge University Press.

Greve, M. \& Nur Orhan, K. (2008). Berlin deutsch-türkisch. Einblicke in die neue Vielfalt. Berlin: Der Beauftragte für Integration und Migration.

Gudjons, H. $\left({ }^{4} 1994\right)$. Handlungsorientiert lehren und lernen. Schüleraktivierung Selbsttätigkeit - Projektarbeit. Bad Heilbrunn: Klinkhardt.

Harris, R. (2003). Language and New Ethnicities - Multilingual Youth and Diaspora. Working Papers in Urban Language \& Literacies, 22.

Hartung, R. (2004). Einführung in das Aufgabengebiet Interkulturelle Erziehung. $3^{\text {rd }}$ ed. Hamburg: Landesinstitut für Lehrerbildung und Schulentwicklung. Retrieved Aug 8, 2008, from http://www.hamburger-

bildungsserver.de/interkulturell/hamburg/einfuehrung.pdf.

Herron, C. (1991). The garden path correction strategy in the foreign language classroom, The French Review, 64, 966-977.

Hinnenkamp, V. (2005). "Zwei zu bir miydi?" - Mischsprachliche Varietäten von Migrantenjugendlichen im Hybriditätsdiskurs, in V. Hinnenkamp \& K. Meng (eds.), Sprachgrenzen überspringen. Sprachliche Hybridität und polykulturelles Selbstverständnis. Tübingen: Narr, 51-103.

Hole, D. \& Klumpp, G. (2000). Definite type and indefinite token: the article son in colloquial German, Linguistische Berichte, 182, 231-244.

Keim, I. (2004). Kommunikative Praktiken in türkischstämmigen Kinder- und Jugendgruppen in Mannheim, Deutsche Sprache, 32, 198-226.

Kern, F. \& Selting, M. (2006). Einheitenkonstruktion im Türkendeutschen. Grammatische und prosodische Aspekte, Zeitschrift für Sprachwissenschaft, 25, 239-272.

Kotsinas, U.-B. (1992). Immigrant adolescents' Swedish in multicultural areas, in C. Palmgren, K. Lövgren \& G. Bolin (eds.), Ethnicity in Youth Culture. Stockholm: University of Stockholm, 43-46.

Kotsinas, U.-B. (2001). Pidginization, creolization and creoloids in Stockholm, Sweden, in N. Smith \& T. Veenstra (eds.), Creolization and Contact. Amsterdam: Benjamins, 125-155.

Kotthoff, H. (2004). Overdoing Culture. Sketch-Komik, Typenstilisierung und Identitätsbildung bei Kaya Yanar, in K. H. Hörning \& J. Reuter (eds.), Doing Culture. Neue Positionen zum Verhältnis von Kultur und sozialer Praxis. Bielefeld: Transkript, 184-201.

Lenerz, J. \& Lohnstein, H. (2005). Nur so - Strukturaspekte der Vergleichskonstruktion, in F. J. d'Avis, (ed.), Deutsche Syntax: Empirie und Theorie. Symposium in Göteborg 13.-15. Mai 2004. Göteborg: Acta Universitatis Gothoburgensis, 81-103.

Loentz, E. (2006). Yiddish, Kanak Sprak, Klezmer, and HipHop: Ethnolect, Minority Culture, Multiculturalism, and Stereotype in Germany, Shofar, 25, 33-62. 
Meehan, T. (1991). It's like, 'What's happening in the evolution of like?': A theory of grammaticalization, Kansas Working Papers in Linguistics, 16, 37-51.

Meyer, H. $\left({ }^{11} 2005\right)$. Unterrichtsmethoden. Vol. 2. Frankfurt/Main: Cornelsen Scriptor.

Milroy, James (1998). "Children Can't Speak or Write Properly Any More", in L. Bauer \& P. Trudgill (eds.), Language Myths. London: Penguin, 58-65.

Ministerium für Bildung, Jugend und Sport des Landes Brandenburg (ed.) (2008). Rahmenlehrplan Deutsch Sekundarstufe 1. Berlin: Wissenschaft und Technik. Retrieved Aug 25, 2008, from http://www.bildung-brandenburg.de/fileadmin/bbs/unterricht_und_pruefungen/ rahmenlehrplaene/sekundarstufe_I/rahmenlehrplaene_2008_05_26/RLP_Deutsc h_Sek1_2008_Brandenburg.pdf.

Neuland, E. (2006). Jugendsprachen - Was man über sie und was man an ihnen lernen kann, in E. Neuland (ed.), Variation im heutigen Deutsch: Perspektiven für den Sprachunterricht. Frankfurt/Main: Lang, 223-241.

Nortier, J. (2001). "Fawaka, what's up?" Language use among adolescents in Dutch mono-ethnic and ethnically mixed groups, in A. Hvenekilde \& J. Nortier (eds.), Meetings at the Crossroads. Studies of Multilingualism and Multiculturalism in Oslo and Utrecht. Oslo: Novus, 61-73.

Pädagogisches Landesinstitut Brandenburg (ed.) (2003). Verbindliche curriculare Vorgaben für den Unterricht in der Qualifikationsphase in der gymnasialen Oberstufe Deutsch. Retrieved Aug 8, 2008, from http://www.bildung-brandenburg.de/fileadmin/bbs/unterricht_und_pruefungen/ pruefungen/abitur/verbindliche_cur_vorgaben/pdf/vcvdeu.pdf.

Paul, K. (2008). Grammatische Entwicklungen in multiethnischer Jugendsprache. Untersuchung zu Verwendungen und Funktionen von "so" in Kiezdeutsch. Master Thesis, University of Potsdam.

Paul, K., Wittenberg, E. \& Wiese, H. (2008). "da gibs so billiardraum" - The interaction of grammar and information structure in Kiezdeutsch. To appear in Proceedings of Jugendsprache, 5. Copenhagen.

Pujolar, J. (2001). Gender, Heteroglossia and Power: A Sociolinguistic Study of Youth Culture. Berlin, New York: Mouton de Gruyter.

Quist, P. (2005). New speech varieties among immigrant youth in Copenhagen - a case study, in V. Hinnenkamp \& K. Meng (eds.), Sprachgrenzen überspringen. Sprachliche Hybridität und polykulturelles Selbstverständnis. Tübingen: Narr, 145-161.

Rampton, B. (1995). Crossing. Language and Ethnicity among Adolescents. London: Longman.

Rampton, B., Harris, R., Georgakopoulou, A., Leung, C., Small, L. \& Dover, C. (2008). Urban Classroom Culture and Interaction: End-of-Project Report. Working Papers in Urban Language \& Literacies, 53.

Silva-Corvalán, C. (1990). Current Issues in Studies of Language Contact, Hispania, $73,162-176$.

Slavin, R. E. (1979). Effects of biracial learning teams on cross-racial friendships. Journal of Educational Psychology, 71, 381-389.

Underhill, R. (1988). Like is, like, focus, American Speech, 63, 234-246.

Wiese, H. (2006). "Ich mach dich Messer": Grammatische Produktivität in KiezSprache (“Kanak Sprak"), Linguistische Berichte, 207, 245-273. 
Wiese, H. (2007). Grammatical reduction and information structural preferences in a contact variety of German: Kiezdeutsch. Request at the Collaborative Research Centre 632 "Information Structure". University of Potsdam. Retrieved Aug 8, 2008, from http://www.sfb632.uni-potsdam.de/projects/B6.pdf.

Wiese, H. (2008). Grammatical innovation in multiethnic urban Europe: New linguistic practices among adolescents. To appear in Lingua.

Williams, A. (2007). Non-standard English and education, in D. Britain (ed.), Language in the British Isles. Cambridge: Cambridge University Press, 401-416.

Wölck, W. (2002). Ethnolects - between bilingualism and urban dialect, in L. Wei, J.M. Dewaele \& A. Housen (eds.), Opportunities and Challenges of Bilingualism. Berlin, New York: Mouton de Gruyter, 157-170.

Zaimoğlu, F. (1995). Kanak Sprak. 24 Mißtöne vom Rande der Gesellschaft. Hamburg: Rotbuch. 